\title{
Self efficacy dalam penggunaan kondom pada Lelaki Seks Lelaki (LSL) dengan HIVIAIDS: Literature review
}

\author{
Nirwanto K. Rahim ${ }^{1 *}$, Sri Yona², Agung Waluyo² \\ 1Pascasarjana Fakultas IImu Keperawatan Universitas Indonesia. *Email: nirwanto.k@ui.ac.id \\ 2Fakultas IImu Keperawatan Universitas Indonesia
}

\author{
Abstract \\ Self-efficacy for condom use related sexual risk behavior among men who have \\ sex with men and HIVIAIDS: A literature review
}

Background: The prevalence of HIV / AIDS in the world is increasing. Men who have sex with men (MSM) is the population most vulnerable to HIV / AIDS. Transmission occurred because of the low use of condoms. Selfefficacy is the ability to belief of self against individual coping in specific situations that affect thinking, behavior, and emotional patterns that can affect attitudes in controlling motivation, behavior, social and the surrounding environment

Purpose: A literature study was explore self-efficacy in using condom and measurement of self-efficacy in condom use

Method: Literature studies used the online database Proquest, CINAHL, the literature was limited by criteria: in 2016-2019, full text and English language, with the keywords: "Self-Efficacy AND Condom Use", "HIV / AIDS AND MSM," HIV / AIDS AND Self Efficacy

Results: Finding 9 articles that were relevant to the inclusion criteria. The results showed that there were two categories in the assessment of self-efficacy in HIV / AIDS patients, namely Sexual Self-Efficacy, and Condom Self-Efficacy

Conclusion: The assessment used several different instruments, however, although the instruments used were different in the assessment of self-efficacy, the results of the entire study showed a link between self-efficacy in the use of condoms in MSM. The results of this literature review can be used as information material about the importance of self efficacy in improving the consistency of condom use to prevent HIV / AIDS

\section{Keywords: HIVIAIDS; Self-Efficacy, Condom Use; Sexual risk; Behavior}

Pendahuluan: Prevalensi HIVIAIDS di dunia semakin meningkat. Lelaki seks lelaki (LSL ) merupakan populasi yang paling mudah terkena HIVIAIDS. Penularan terjadi karena rendahnya penggunaan kondom. Self-efficacy merupakan kemampuan untuk percaya pada kemampuan diri terhadap koping individu dalam situasi yang spesifik yang mempengaruhi pemikiran, perilaku, dan pola emosional yang dapat berdampak pada sikap dalam mengontrol motivasi, perilaku, dan sosial serta lingkungan sekitar.

Tujuan: Untuk mengeksplorasi self-efficacy dalam penggunaan kondom dan pengukuran self-efficacy dalam penggunaan kondom.

Metode: Studi literatur melalui database online Proquest, CINAHL, literature dibatasi dengan kriteria : tahun 2016-2019, full text dan berbahasa Inggris, dengan kata kunci: "Self-Efficacy AND Condom Use","HIVIAIDS AND MSM,"HIVIAIDS AND Self Efficacy

Hasil: Didapatkan self-efficacy pada pasien HIVIAIDS dibedakan menjadi Sexual Self- Efficacy, dan Condom Self-Efficacy dan penilaian menggunakan beberapa instrument yakni sexual self-efficacy scale, the AIDSPrevention Self-efficacy Scal, condom use self-efficacy, condom use self-efficacy scale,

Simpulan: terdapat instrumen yang berbeda namun, meskipun instrumen yang digunakan berbeda dalam penilaian self-efficacy namun seluruh hasil penelitan menunjukkan adanya keterkaitan self-efficacy dalam penggunaan kondom pada LSL. Hasil telaah literature ini dapat dijadikan bahan informasi tentang pentingnya self efficacy dalam meningkatkan konsistensi penggunaan kondom untuk mencegah HIVIAIDS.

Kata Kunci: Self-Efficacy; Kondom; Resiko; HIVIAIDS; Hubungan seks 


\section{PENDAHULUAN}

Meningkatnya data WHO menunjukkan jumlah penderita HIV pada tahun 2018 mencapat 37.9 juta, 1.7 juta orang lainnya merupakan kasus baru (WHO, 2019). Man Who Have Sex With Man (MSM) atau lelaki seks lelaki (LSL) merupakan populasi yang paling mudah terkena HIVIAIDS 27 kali lebih mungkin tertular daripada populasi lainnya (UNAIDS, 2019). Faktanya prevalensi HIV di populasi ini di setiap negara semakin berkembang, faktor utama penularan virus ini adalah rendahnya penggunaan kondom sebagai proteksi saat melakukan seks anal (CDC, 2018).

Penggunaan kondom merupakan tindakan pencegahan penularan virus HIV, antusias penggunaan kondom saat ini tercatat yakni hanya sekitar $4-52.3 \%$ pada individu yang aktif dalam melakukan aktivitas seksual yang berarti bahwa masih terdapat individu yang tidak konsisten dalam penggunaan kondom (Ajayi, Ismail, \& Akpan, 2019). Bebeberapa studi telah melaporkan bahwa terdapat beberapa faktor yang memiliki keterkaitan erat dengan ketidakkonsistenan penggunaan kondom seperti faktor kognitif, dan beliefs (Manjengwa et al., 2019), jumlah pasangan (Dawson et al., 2019), tipe pasangan seksual (Ajayi, Ismail, \& Akpan, 2019).

Studi lainnya mengidentifikasi bahwa kemampuan menegosiasi, dan berkomunikasi dengan pasangan merupakan faktor yang mendasari seseorang memutuskan untuk menggunakan kondom dalam melakukan seks, kemampuan ini seringkali dikenal dengan istilah Sefl-efficacy atau efikasi diri (Ajayi, Ismail, \&
Akpan, 2019; Closson et al., 2017; Dawson et al., 2019; Khumsaen \& Stephenson, 2017; Li et al., 2017; Manjengwa et al., 2019). Self -efficacy merupakan kemampuan seseorang untuk tetap konsisten tanpa merasa malu atau ditolak untuk melakukan suatu perilaku . (Wong, 2017).

Kemampuan ini akan mempengaruhi bagaimana seorang individu akan berpikir, bertindak untuk melindungi diri dengan cara berkomunikasi, menegosiasi terkait penggunaan kondom (Asante, 2016). Self-efficacy sendiri dinilai sebagai salah satu faktor penting yang dapat digunakan untuk memprediksi kemungkinan seseorang untuk bersikap konsisten dalam penggunaan kondom (Ajayi, Ismail, et al., 2019; Ajayi, Olawale, \& Id, 2019). Tujuan studi literature ini untuk mengeksplorasi bagaimana self-efficacy pada LSL dalam penggunaan kondom.

\section{METODE PENELITIAN}

Metode penulisan artikel ini menggunakan penelusuran literatur. Studi literatur melalui database online Proquest, Cumulative Index to Nursing and Allied Heath Literature (CINAHL), literature dibatasi dengan kriteria : tahun 20162019, full Text dan Berbahasa Inggris. dengan kata kunci: "Self-Efficacy AND Condom Use", "HIVIAIDS AND MSM,"HIVIAIDS AND Self Efficacy. Untuk mendapatkan literatur yang relevan maka pencarian dibatasi dengan melihat desain penelitian (artikel penelitian : kualitatif dan atau kuantitatif ),subjek penelitian (anak muda, LSL), dan kesamaan artikel dari kedua data base, sehingga didapatkan 9 literaure yang terkait 


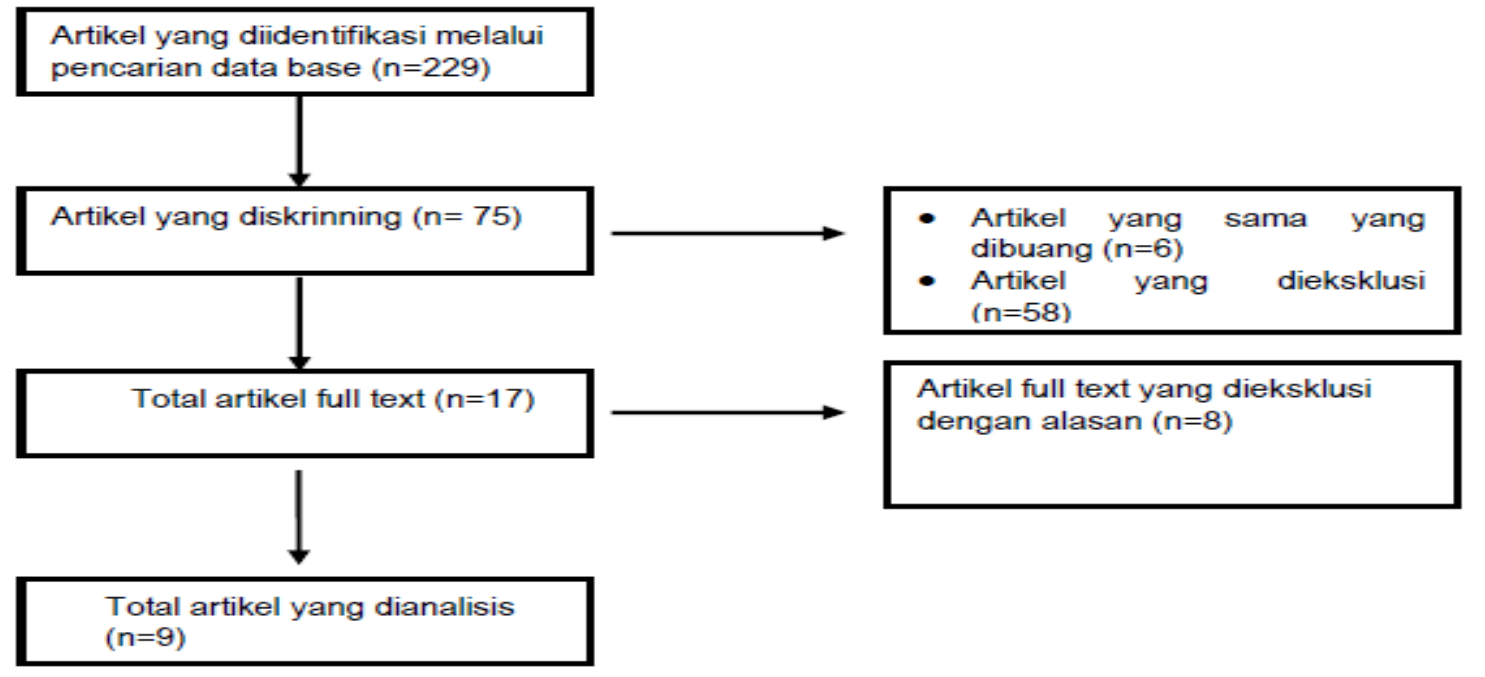

Dari telaah literature yang ditemukan terdapat 9 lieratur yang relevan dengan topik bahasan. Penelitian ini membahas tentang bagaimana, representasi HIV/ AIDS pada LSL dan kaitannya terhadap self- efficacy pada penyakit kronis serta bagaimana self-efficacy dan hubungannya dengan konsistensi penggunaan kondom. Secara umum 9 literatur yang relevan disajikan dalam tabel 1. Hasil telaah literature didapatkan 3 kata kunci yang ditemukan untuk lebih memhami bagaimana self efficacy pada penggunana kondom yang terdiri dari deskripsis representasi HIVIAIDS LSL dan kaitannya dengan self-efficacy, jenis self- efficacy dan pengukuran self-efficacy dalam penggunaan kondom.

Nirwanto K. Rahim ${ }^{1 *}$, Sri Yona ${ }^{2}$, Agung Waluyo ${ }^{2}$

'Pascasarjana Fakultas llmu Keperawatan Universitas Indonesia. *Email: nirwanto.k@ui.ac.id

${ }^{2}$ Fakultas Ilmu Keperawatan Universitas Indonesia 
Hasil

Tabel 1. Tabel Review Artikel

\begin{tabular}{|c|c|c|c|c|c|}
\hline Tahun & Penulis & Tujuan & Metode & Sampel & Temuan \\
\hline 2017 & $\begin{array}{l}\text { (Khumsaen \& } \\
\text { Stephenson, } \\
\text { 2017) }\end{array}$ & $\begin{array}{l}\text { Untuk mengetahui hubungan HIV/AIDS belief self- } \\
\text { efficacy untuk pencegahan perilaku AIDS, } \\
\text { Persepsi HIV sebagai penyakit kronis, dan perilaku } \\
\text { beresiko HIV pada LSL muda. }\end{array}$ & $\begin{array}{l}\text { Studi penelitan Deskriptif } \\
\text { kuantitatif } \\
\text { Cross sectional }\end{array}$ & $\mathrm{n}=469$ sampel & $\begin{array}{l}\text { EHBM (expanded health belief model) digunakan untuk } \\
\text { menilai persepsi HIV, intervensi AIDS Health Beliefs dan } \\
\text { Self-Efficacy sebagai bentuk pencegahan Perilaku beresiko. }\end{array}$ \\
\hline 2019 & $\begin{array}{l}\text { (Manjengwa et } \\
\text { al., 2019) }\end{array}$ & $\begin{array}{l}\text { Untuk mengetahui personal beliefs, persepsi, } \\
\text { pemikiran, dan tindakan yang dikaitkan dengan } \\
\text { Multiple Sex Partnership (MSP) dan Non Use } \\
\text { Condom (NCU }\end{array}$ & $\begin{array}{l}\text { Studi penelitian } \\
\text { Deskriptif kuantitatif } \\
\text { Cross sectional }\end{array}$ & $\begin{array}{l}\mathrm{n}=10.000 \\
\text { sampel }\end{array}$ & $\begin{array}{l}\text { Determinan dari Multiple Sex Partnership (MSP) dan Non } \\
\text { Use Condom (NCU) Konstruksi kognitif : persepsi } \\
\text { kerentanan rendah terhadap infeksi HIV, dan persepsi } \\
\text { manfaat yang tinggi serta perilaku mempunyai korelasi yang } \\
\text { kuat dengan perilaku beresiko. }\end{array}$ \\
\hline 2019 & $\begin{array}{l}\text { (Ajayi, Ismail, et } \\
\text { al., 2019) }\end{array}$ & $\begin{array}{l}\text { Untuk memahami faktor-faktor yang mempengaruhi } \\
\text { penggunaan kondom secara konsisten di kalangan } \\
\text { remaja dan dewasa muda di Nigeria }\end{array}$ & $\begin{array}{l}\text { Studi penelitian } \\
\text { kuantitatif Cross } \\
\text { sectional }\end{array}$ & $\mathrm{N}=498$ sampel & $\begin{array}{l}\text { Condom Self-efficacy, tipe pasangan seksual, dan } \\
\text { berdiskusi tentang HIV dengan pasangan memiliki } \\
\text { hubungan yang signifikan dengan penggunaan kondom } \\
\text { yang konsisten. }\end{array}$ \\
\hline 2019 & $\begin{array}{l}\text { (Dawson et al., } \\
\text { 2019) }\end{array}$ & $\begin{array}{l}\text { Menilai hubungan antara ketahanan, self-efficacy } \\
\text { penggunaan kodom, homophobia internal dan seks } \\
\text { anal tanpa kondom diantara pria kulit hitam yang } \\
\text { berhubungan seks dengan pria. }\end{array}$ & $\begin{array}{l}\text { Studi penelitian } \\
\text { kuantitatif cross } \\
\text { sectional }\end{array}$ & $\mathrm{n}=22$ sampel & $\begin{array}{l}\text { Perilaku berhubungan seks anal tanpa kondom mempunyai } \\
\text { keterkaitan hubungan dengan memiliki lebih dari satu } \\
\text { pasangan seks dsn self-efficacy penggunaan kondom. }\end{array}$ \\
\hline
\end{tabular}

\section{Nirwanto K. Rahim ${ }^{1 *}$, Sri Yona ${ }^{2}$, Agung Waluyo ${ }^{2}$}

'Pascasarjana Fakultas Ilmu Keperawatan Universitas Indonesia. *Email: nirwanto.k@ui.ac.id

${ }^{2}$ Fakultas Ilmu Keperawatan Universitas Indonesia 
2016 (Asante, 2016)

Penelitian bertujuan untuk meneliti bagaimana mengukur self-efficacy : menggunakan condom use self-efficacy scale bisa memprediksikan penggunaan kondom actual dan niat penggunan kondom diantara masyarakat Ghana.

\section{Penelitian ini bertujun untuk mengetahuan} hubungan antara peran mediasi teman sebaya dan self-efficacy dengan keterlibatan komunitas dalam penggunaan kondom

2018 (Belil, Alhani, \& Studi ini bertujun unutk mengeksplor berbagai Ebadi, 2018.) aspek self-efficacy diantara pasien dengan kondisi kronis berdasarkan Familily Ceneterd Empowerment Model (FCEM).

2017 (Luévano-flores Untuk mengetahui representasi sosial HIVIAIDS \& Rubia, 2017b) pada LSL

\section{Studi penelitian kuantitatif cross sectional} kuantitatif cross sectional.

Studi penelitian kualitatif dengan wawancara sem terstruktur.

Studi Peneltian : Eksplorasi kualitatif , trans-sectional nonexperimental design. $\mathrm{n}=518$ sampel Penggunaan The Condom Uses Self-Efficacy Scale

(CUSES-G) adalah ukuran yang tepat, dan bisa digunakan untuk menilai dan memprediksi penggunaan kondom di kalangan anak muda mahasiswa di Ghana. Hasil juga menambah literatur yang ada pada kemampuan efikasi diri kondom dapat memprediksi penggunaan kondom actual dan niat untuk menggunakan kondom

$\mathrm{n}=1042 \quad$ Studi ini menjunjukkan bahwa penggunana kondom sampel dengan mediasi teman sebaya dan self-efficacy menjadi mediator pada keterlibatan penggunaan kondom pada komunitas.

n= 22 sampel Hasil dari penelitan ini mengindikasikan self-efficacy pada pasien terdiri dari kognitif, dimensi psiko-emosional, fungsional, dan sosial yang dapat digunakan untuk menilai pemberdayaan.

$\mathrm{n}=25$ sampel Didaptkan bahwa HIVIAIDS direpresentasilan sebagai penyakit mematikan yang disebabakan oleh virus (HIV) yang menyebar saat berhubungan seks. Representasi in sangat dibebani HIVIAIDS sebagai dengan gambaran , kepercayaan atau ketakutan akan terinfeksi atau dikutuk secara sosial 


\section{PEMBAHASAN}

\section{Deskripsi Representasi HIVIAIDS LSL dan Kaitannya dengan Self-efficacy}

Representasi sosial menunjukkan pemahaman pengetahuan dan keyakinan sosial yang dimilki oleh komunitas mayarakat dalam menunjukkan pola ekspresi terhadap sebuah fenomena, dimana pemahaman ini dinilai penting karena dapat mencapai bagaimana fenomena tersebut dapat dimodifikasi, yang dapat mempengaruhi perilaku pencegahan (Robles, 2016).

HIVIAIDS direpresentasikan sebagai penyakit yang mematikan yang disebabkan oleh virus HIV, menyebar saat berhubungan seks, representasi ini juga dibebani dengan kepercayaan atau ketakutan terkait infeksi dan dikutuk secara sosialrepresentasi ini memungkinkan dalam melakukan pencegahan perilaku beresiko (Luévano-flores \& Rubia, 2017a). HIVIAIDS merupakan penyakit yang disebabkan karena perilaku beresiko. Pengetahuan tentang HIV dan AIDS merupakan indkator utama dalam memungkinkan terjadinya perubahan perilaku. penelitian yang dilakukan Manjengwa et al (2019) mendapatkan bahwa konstruksi kognitif (persepsi kerentanan rendah terhadap infeksi hiv, dan persepsi manfaat yang tinggi) (Suciati, 2017; Fauziah, Shaluhiyah, \& Prabamurti, 2018; Teddy, 2019)

Peningkatan pencegahan perilaku beresiko erat kaitanya dengan bagaimana MSM percaya dengan kemampuannya dalam melakukan hubungan seksual dengan aman misalnya dalam penggunaan kondom, kepercayaan akan kemampuan diri ini lebih dikenal dengan istilah self-effcacy (Asante, Osafo \& Doku, 2016; Kana , Nayoan \& Limbu, 2016).

Self-efficacy merupakan konsep multi struktural, yang beragam. Berbagai macam definisi menjelaskan terkait konsep self-efficacy. Selfefficacy merupakan istilah yang menunjukkan sebuah kemampuan untuk percaya pada kemampuan diri terhadap koping individu dalam situasi yang spesifik yang mempengaruhi pemikiran, perilaku, dan pola emosional yang dapat berdampak pada sikap dalam mengontrol motivasi, perilaku, dan sosial serta lingkungan sekitar (Asante, Osafo \& Doku, 2016; Belil, Alhani, \& Ebadi, 2018).
Studi kualitatif oleh Belil, Ahani \& Ebadi. (2018) terkait self efficacy pada penyakit kronis dijelaskan bahwa self-efficacy merupakan kemampuan individu dalam mengembangkan pengetahuan dan pemahaman yang kaitannya dengan penyakit, sebuah kemampuan dalam mengelola aktifitas sehari-sehari,kemampuan dalam merencanakan gaya hidup, kemampuan dalam hubungan interpersonal yang baik.

\section{Hal-hal mempengaruhi self-efficacy}

condom self efficacy pada LSL dipengaruhi oleh beberapa hal seperti: tipe pasangan seksual, dan berdiskusi dengan pasangan memiliki korelasi dengan penggunaan kondom yang konsisten. Closson et al (2017) menjelaskan bahwa jenis kelamin dapat mempengaruhi self-efficacy. Dalam peneltiannya didapatkan bahwa pria yang memiliki sexual self-efficacy yang tinggi ditemukan bahwa berhubungan erat dengan penggunaan kondom. Selain jenis kelamin, jumlah pasangan seks juga berhubungan dengan condom self-efficacy. Dawson et al (2019) mengungkapkan dalam penelitiannya jumlah pasangan seks dan selfefficacy mempunyai hubungan dengan perilaku melakukan seks anal tanpa kondom. Li et al (2017) menjelaskan bahwa peran teman sebaya dan selfefficacy dapat menjadi mediator pada keterlibatan penggunaan kondom (Tiara \& Mutahar, 2019).

\section{Pengukuran Sexual Self-Efficacy dan Condom Self-Efficacy}

Tujuan dari pengukuran ini adalah untuk melihat kemampuan individu dan mengukur tingkat kepercayaan dalam mencegah perilaku beresiko. Namun beberapa penelitian dalam penelitiannya menggunakan instrumen yang berbeda. Sexual self-efficacy merupakan kemampuan individu untuk melakukan hubungan atas kemauan sendiri, melakukan seks yang menyenangkan, dan penggunaan konstrasepsi. Untuk mengukurnya banyak skala yang dapat digunakan, misalnya sexual self-efficacy scale (Closson et al., 2017). Sexual self-efficacy scale merupakan skala yang mengukur SSE dengan menggunakan 6-item, yang di adaptasi dari penelian terkait HIV pada remaja Afrika (Louw J, Peltzer K, 2012).

Closson et al (2017), dalam penelitiannya menggunakan skala ini, contoh pertanyaanya seperti "apakah anda menghindari seks kapan saja 
ketika anda tidak mau melakukannya?". Skor skala penilaian ini menggunakan skala likert dengan hasil skor mulai dari 6 hingga 24 dengan titik potong $\geq 18$ yang dinilai sebagai SSE tinggi. Instrument ini memiliki tingkat sensitivitas $84 \%$ dan spesifitas 100\% dengan skor kappa $=0.73$.

Khumsaen \& Stephenson (2017), dalam penelitiannya menggunakan instrument selfefficacy yang disebut the AIDS-Prevention Selfefficacy Scale. Skala ini merupakan skala yang digunakan dan telah divalidasi pada penelitan sebelumnya oleh Kasen tahun 1992. Instrumen ini terdiri dari 3 domain yakni self-efficacy dalam menolak hubungan seksual, self-efficacy dalam dalam penggunaan kondom. Instrumen ini terdiri dari 22 item dengan total skor 22-110. Skor tertinggi menunjukkan self-efficacy tinggi untuk terlibat dalam perilaku pencegahan HIV. Reliability menggunakkan cronbach alpha dengan nilai 0.90 . Selain digunakan dalaam pengukuran aktivitas seksual self-efficacy digunakan juga untuk melihat konsistensi penggunaan kondom. Instrument yang digunakan dalam menilai ini yakni Condom selfefficacy scale.

Instrumen condom self efficacy diukur dengan menggunakan 13 pertanyaan yang yang diukur menggunakan skala likert dengan contoh pertanyaanya "saya merasa percaya diri dengan kemampuan saya untuk menggunakan kondom pada diri saya atau pasangan saya, "saya merasa yakin bahwa saya bisa membeli kondom tanpa perasaan malu". Instrumen ini menggunakan skala likert 1-3, Skor maksimum pada instrument ini yakni 39 dengan skor tinggi menunjukkan condom self-efficacy tinggi, dan sebaliknya. Instrumen ini mempunyai nilai cronbach alpha 0.811 (Ajayi, Ismail, et al., 2019).

Selain itu Wilkerson et al (2019), dalam penelitiannya menggunakan instrumen condom use self-efficacy yang berbeda dari sebelumnya dimana instrumen ini menggunakan 11 item dan partisipan akan ditanya terkait apakah mereka dapat menggunakan kondom di berbagai situasi. Item akan dinilai menggunakan skala ordinal 1-5, dengan nilai tertinggi menunjukkan self-efficacy yang tinggi dengan nilai cronbach alpha 0.90 . Dawson et al (2019), menggunakan skala condom use self-efficacy scale yang terdiri dari 27 item yang merupakan instrument untuk mengukur kepercayaan diri seseorang atau pasangan dalam menggunakan kondom. Contoh pertanyaanya yakni "saya bisa mengatakan tidak untuk melakukan hubungan seks dengan pasangan baru jika tidak memliki kondom bahkan jika saya ingin memiliki hubungan". Skala ini diukur menggunakan skala likert 1-5 (tidak yakin-sepenuhnya yakin). Skor pada item berkisar 27-135 dimana skor tertinggi menunjukkan condom self-efficacy yang tinggi. Skala ini memiliki reliabilitas internal dengan (Cronbach's $a=0,97)$. Penelitian lainnya oleh Asante, Osafo \& Doku, (2016) menggunakan instrumen The Condom Uses Self-Efficacy Scale (CUSES-G) dengan 14 pertanyaan misalnya "saya tidak akan merasa percaya diri untuk menyarankan menggunakan kondom dengan pasangan baru karena saya takut dia akan berpikir saya punya penyakit menular seksual". Instrument ini menggunakan skala likert 1-5 (sangat tidak setujusangat setuju).Total skor berkisar dari 0-56 dengan skor tinggi menunjukkan persepsi yang mempertanyakan potensial pasangan seks, dan tinggi terhadap penggunaan kondom, koefisien cronbach alpha 0.91 .

$\mathrm{Li}$ et al (2017) dalam penelitiannya menggunakan instrumen dengan 7 item pertanyaan. Partisipan akan ditanya mengenai seberapa nyaman perasaanan mereka ntuk melakukan negosisasi dengan menggunakan kondom dengan pasangan. Jawaban akan dinilai menggunakan skala likert 1-5 (sangat tidak setujusangat setuju). Instrument ini memiliki nilai Cronbach alpha 0.823 .

\section{SIMPULAN}

Berdasarkan hasil studi literatur dapat disimpulkan bahwa self efficacy pada penggunaan kondom merupakan kemampuan idividu percaya terkait kemampuannya dalam merubah perilaku terkait penggunaan kondom. Pemahaman perawat terkait self-efficacy, walaupun pneggunaan instrumen yang berbeda untuk mengukur selfeffiacy namun hasil yang diperoleh dapat menggambarkan keterkaitan self-efficacy dalam penggunaan kondom pada LSL.

\section{SARAN}

Hasil telaah literature ini dapat dijadikan bahan informasi tentang pentingnya self efficacy dalam meningkatkan konsistensi penggunaan kondom untuk mencegah HIVIAIDS. 


\section{DAFTAR PUSTAKA}

Ajayi, A. I., Ismail, K. O., \& Akpan, W. (2019). Factors associated with consistent condom use: a cross-sectional survey of two Nigerian universities. BMC public health, 19(1), 1207.

Ajayi, A. I., Olawale, E., \& Id, O. (2019). What predicts self-efficacy? Understanding the role of sociodemographic , behavioural and parental factors on condom use self- efficacy among university students in Nigeria, 1-20. https://doi.org/10.1371/journal.pone.0221804

Asante, K. O. (2016). The Role of Condom Use Self-Efficacy on Intended and Actual Condom Use Among University Students in Ghana. Journal of Community Health, 41(1), 97-104. https://doi.org/10.1007/s10900-015-0073-6

Asante, K. O., Osafo, J., \& Doku, P. N. (2016). The role of condom use self-efficacy on intended and actual condom use among university students in Ghana. Journal of community health, 41(1), 97-104.

Belil, E. F., Alhani, F., Ebadi, A., \& Kazemnejad, A. (2018). Self-efficacy of people with chronic conditions: A qualitative directed content analysis. Journal of clinical medicine, $7(11)$, 411. https://doi.org/10.3390/jcm7110411

Centers for Disease Control and Prevention. (2018). HIV and Gay and Bisexual Men. Retrieved from https://www.cdc.gov/hiv/group/msm/index.html

Closson, K., Dietrich, J. J., Lachowsky, N. J., Nkala, B., Palmer, A., Cui, Z., \& Kaida, A. (2018). Gender, sexual self-efficacy and consistent condom use among adolescents living in the HIV hyper-endemic setting of Soweto, South Africa. AIDS and Behavior, 22(2), 671-680.
Closson, K., Janine, J., Nathan, D., Nkala, B., Palmer, A., Cui, Z., ... Kaida, A. (2017). Gender , Sexual Self -Efficacy and Consistent Condom Use Among Adolescents Living in the HIV Hyper - Endemic

Dawson, E. L., Mendoza, M. C., Gaul, Z., Jeffries Iv, W. L., Sutton, M. Y., \& Wilson, P. A. (2019). Resilience, condom use self-efficacy, internalized homophobia, and condomless anal sex among black men who have sex with men, New York City. PloS one, 14(4), e0215455.

Fauziyah, F., Shaluhiyah, Z., \& Prabamurti, P. N. (2018). Respon Remaja Lelaki Suka Lelaki (LSL) dengan Status HIV Positif terhadap Pencegahan Penularan HIV kepada Pasangan. Jurnal Promosi Kesehatan Indonesia, 13(1), 17-31.

Kana, I. M., Nayoan, C. R., \& Limbu, R. (2016). Gambaran perilaku pencegahan hiv dan aids pada lelaki suka lelaki (IsI) di kota kupang tahun 2014. Unnes Journal of Public Health, 5(3), 252-262.

Khumsaen, N., \& Stephenson, R. (2017). Beliefs and perception about HIVIAIDS, self-efficacy, and HIV sexual risk behaviors among young Thai men who have sex with men. AIDS Education and

Li, H., Xue, L., Tucker, J. D., Wei, C., Durvasula, M., Hu, W., \& Kang, D. (2017). Condom use peer norms and self-efficacy as mediators between community engagement and condom use among Chinese men who have sex with men, 1-9. https://doi.org/10.1186/s12889-0174662-4 
Louw, J., Peltzer, K., \& Chirinda, W. (2012). Correlates of HIV risk reduction self-efficacy among youth in South Africa. The Scientific World Journal, 2012.

Luévano-flores, P. A., \& Rubia, J. M. (2017b). An exploratory qualitative study on the social representation of HIV / AIDS in young men who have sex with men. Medicina Universitaria, 19(77),

170-177. https://doi.org/10.1016/j.rmu.2017.10.006

Manjengwa, P. G., Mangold, K., Musekiwa, A., Kuonza, L. R., Field, S. A., \& Training, E. (2019). Cognitive and behavioural determinants of multiple sexual partnerships and condom use in South Africa: Results of a national survey, $1-9$.

Robles, A. (2016). The social construction and social representation of HIV: an anthropological study. Med Soc, 18-22.

Suciati, M. (2017). Hubungan Harga dan Kontrol Diri Dengan Perilaku Pencegahan HIVIAIDS LSL (Lelaki Seks Lelaki) Di Kota Padang Tahun 2017 (Doctoral dissertation, Universitas Andalas)
Teddy, A. (2019). Studi fenomenologi: pengalaman emosional lelaki seks lelaki (IsI) dengan HIV post pemberitahuan serostatus positif di Puskesmas Simpang Kawat Kota Jambi (Doctoral dissertation, Universitas Andalas).

Fatriani, V. E. T. Y., \& Mutahar, R. (2019). Hubungan persepsi berisiko dengan pemanfaatan tes HIV pada lelaki seks dengan lelaki (LSL) di Indonesia (Analisis Data STBP Tahun 2015) (Doctoral dissertation, Sriwijaya University).

UNAIDS. (2019). Global HIV \& AIDS statistics 2019 fact sheet. Retrieved from https://www.unaids.org/en/resources/fact-sheet

World Health Organization. (2019). Global Health Observatory (GHO) data. Retrieved from https://www.who.int/gho/hiv/en/

Wilkerson, J. M., Rhoton, J. M., Li, D., Rawat, S. A., Patankar, P., Rosser, B. S., \& Ekstrand, M. (2019). Information, Motivation, and SelfEfficacy Among Men Who Have Sex With Men and Transgender Women in the State of Maharashtra, India. Health Education \& Behavior, 46(2), 304-311. 